\title{
Cross-cultural adaptation and analysis of the psychometric properties of the Balance Evaluation Systems Test and MiniBESTest in the elderly and individuals with Parkinson's disease: application of the Rasch model
}

Angélica C. Maia ${ }^{1}$, Fátima Rodrigues-de-Paula ${ }^{2}$, Lívia C. Magalhães ${ }^{3}$, Raquel L. L. Teixeira ${ }^{1}$

\begin{abstract}
Background: Older adults and individuals with neurological problems such as Parkinson's disease (PD) exhibit balance deficits that might impair their mobility and independence. The assessment of balance must be useful in identifying the presence of instability and orient interventions. Objective: To translate and perform a cross-cultural adaptation of the Balance Evaluation Systems Test (BESTest) and MiniBESTest to Brazilian Portuguese and analyze its psychometric properties. Method: The tests were translated and adapted to Portuguese according to a standard method and then subjected to a test-retest reliability assessment (10 older adults; 10 individuals with PD). The psychometric properties were assessed by the Rasch model ( 35 older adults; 35 individuals with PD). Results: The reliability coefficient of the tests relative to the items and subjects varied from 0.91 and 0.98 , which is indicative of the stability and reproducibility of the measures. In the BESTest, the person (4.19) and item (5.36) separation index established six balance ability levels and seven levels of difficulty, respectively. In the MiniBESTest, the person (3.16) and item (6.41) separation index established four balance ability levels and nine levels of difficulty, respectively. Two items in the BESTest did not fit with the model expectations, but the construct validity was not compromised. No item in the MiniBESTest was erratic. Conclusions: The results corroborate the diagnostic and screening functions of the BESTest and MiniBESTest, respectively, and indicate that the Brazilian versions exhibit adequate reliability, construct validity, response stability, and capacity to distinguish among various balance ability levels in older adults and individuals with PD.
\end{abstract}

Keywords: postural balance; physical therapy; Parkinson's disease; older adults; cross-cultural adaptation; Rasch analysis.

\section{HOW TO CITE THIS ARTICLE}

Maia AC, Rodrigues-de-Paula F, Magalhães LC, Teixeira RLL. Cross-cultural adaptation and analysis of the psychometric properties of the Balance Evaluation Systems Test and MiniBESTest in the elderly and individuals with Parkinson's disease: application of the Rasch model. Braz J Phys Ther. 2013 May-June; 17(3):195-217. http://dx.doi.org/10.1590/S1413-35552012005000085

\section{Introduction}

Posture control (PC) is the ability to maintain the projection of the body center-of-mass within the limits of the base of support under static and dynamic conditions and involves the control of the body position in space for the purpose of ensuring stability and orientation ${ }^{1}$. PC depends on the visual, vestibular, somatosensory, nervous, biomechanical, and cognitive systems ${ }^{1,2}$ that are exposed to different types of dysfunctions.

Older adults are liable to acquire balance disorders as a function of multiple impairments, such as multisensory loss, muscle weakness, and orthopedic and cognitive limitations ${ }^{3}$. Such impairments cause functional losses, and the balance disorders must be appropriately assessed and treated due to their impact on the quality of life and their high financial onus relative to their health care costs ${ }^{4,5}$. In addition, several neurological conditions are associated with postural instability, with Parkinson's disease (PD) being the most common movement disorder. The estimated prevalence of PD is $100-200$ cases $/ 100,000$ inhabitants ${ }^{6}$. From the clinical point of view, PD is characterized by motor dysfunctions such as bradykinesia, tremor, and rigidity. Postural instability tends to appear during the course of the disease and is associated with falls, limited mobility and independence ${ }^{7}$.

\footnotetext{
${ }^{1}$ Physical therapist, Belo Horizonte, MG, Brazil

${ }^{2}$ Department of Physical Therapy, Universidade Federal de Minas Gerais (UFMG), Belo Horizonte, MG, Brazil

${ }^{3}$ Department of Occupational Therapy, UFMG, Belo Horizonte, MG, Brazil

Received: 03/30/2012 Revised: 08/23/2012 Accepted: 01/20/2013
} 
Balance disorders are some of the most common problems treated by physical therapists. These health professionals need to identify the patients' instability and select the most appropriate approach to rehabilitation ${ }^{8}$. The current clinical tests for balance assessment focus on the detection of balance disorders and the prediction of the risk of falls ${ }^{9-13}$. The Berg Balance Scale is one of the most widely used tests. Its ceiling effect has been identified in the evaluation of more subtle balance disorders that occur in older adults or at the initial stages of $\mathrm{PD}^{12-14}$.

Horak et al. ${ }^{8}$ formulated the Balance Evaluation Systems Test (BESTest) to help in the identification of the particular system that may be responsible for poor balance and thus guide the treatment. The BESTest is a versatile instrument that might be applied to individuals at any age and with a broad scope of diseases and severity levels ${ }^{8}$. It comprises 27 items and a total of 36 tasks. The items are clustered in sections corresponding to the six underlying systems that may constrain balance: biomechanical, stability limits, postural responses, anticipatory postural adjustments, sensory orientation, and dynamic balance during gait. Each item is scored on an ordinal four-point scale varying from zero to three (best performance). A shorter version known as the MiniBESTest ${ }^{14}$ comprises 14 of the items from the full version. As its application is faster than the full version, it is useful to screen dynamic balance disorders ${ }^{14}$.

Both the BESTest and MiniBESTest were originally elaborated in English. Thus, they must be translated and cross-culturally adapted, and their psychometric properties must be assessed ${ }^{15}$. Therefore, the aims of the present study were to translate and conduct the cross-cultural adaptation of the BESTest and MiniBESTest to Brazilian Portuguese and to analyze their psychometric properties in older adults and individuals with PD.

\section{Method}

\section{Participants}

The study comprised a convenience sample including 35 older adults recruited in the community and 35 individuals with idiopathic PD diagnosed and recruited at the university outpatient clinic. The two groups included individuals from both genders. Nonetheless, volunteers with cognitive deficits on the Mini Mental State Examination (MMSE) ${ }^{16,17}$ or adverse clinical conditions, such as hemodynamic and/or clinical instability, were excluded. The group of older adults comprised individuals aged 65 years old or older and volunteers previously diagnosed with balance-affecting illnesses were excluded. The group of PD patients comprised individuals aged 50 years old or older, and those volunteers exhibiting other neurological diseases were excluded. The patients with PD were assessed within one hour from the intake of antiparkinsonian medication.

The study was approved by the Research Ethics Committee of the Universidade Federal de Minas Gerais - UFMG, Belo Horizonte, MG, Brazil and the participants signed informed consent forms.

\section{Procedures and instruments of measures}

\section{Translation and cross-cultural adaptation}

The process of translation and cross-cultural adaptation followed the method suggested by Beaton et al. ${ }^{18}$, which consists of six stages.

In stage one, the instruments were translated into Brazilian Portuguese by two independent bilingual translators who were native Portuguese speakers. In stage two, the two translations were synthesized into one consensus version, which was used as the basis for backward translation (stage three). This backward translation was performed by two independent translators who were native English speakers. These translators were blinded to the study aims and had no formal training in the health sciences. In stage four, the final version of the instruments was revised by a panel of experts, who were charged with consolidating the questionnaires and prepare the prefinal version ${ }^{18}$.

In stage five, the instruments were subjected to pretesting, during which they were applied to 10 older adults and 10 individuals with PD. The participants expressed no doubts as to the meaning of the BESTest items, and the responses showed no ambiguity; therefore, no changes had to be made to the translated version. In the case of the MiniBESTest, the examiner expressed doubts with the scoring of items seven and eight. The authors of the original version were contacted and recommended modifying the wording of the last sentence of the examiner's instructions in the corresponding items to "Include inclination or hip strategy as 'instability', and score one level below". Thus, the final Brazilian versions of the BESTest (Appendix 1) and MiniBESTest (Appendix 2) were concluded. Communication with the authors of the original instruments was maintained throughout the entire process to improve the final version (stage $\operatorname{six})^{18}$. 
First, clinical, demographic, and anthropometric data were collected. Next, the volunteers were evaluated with BESTest and MiniBESTest by a trained examiner. The disease severity of the individuals with PD was rated according to the Hoehn and Yahr Scale (HY) ${ }^{19,20}$. Patients in stage 0 (zero) do not exhibit any sign of disease, those in stages 1 to 2.5 exhibit mild disability, those in stage 3 exhibit moderate disability, and those in stages 4 and 5 exhibit severe disability ${ }^{21}$. The individuals with PD were also assessed by the Motor Examination of the Unified Parkinson's Disease Rating Scale (UPDRS) ${ }^{22}$, which serves to assess the progression of PD and the effects of therapeutic interventions ${ }^{22}$.

\section{Test-retest reliability}

To test their reliability, the BESTest and the MiniBESTest were applied twice with a seven-day interval to the first 10 older adults and the first 10 individuals with PD included in the study. The reliability of the tests was assessed by the intraclass correlation coefficient (ICC).

\section{Statistical analysis}

Descriptive statistics were used to characterize the sample. The ICC was calculated using software SPSS for Windows version 17.0.

According to Portney and Watkins ${ }^{23}$, the test-retest reliability is appropriate when ICC $>0.75$, whereas ICC $<0.75$ indicates poor to moderate reliability.

The final versions of the instruments were assessed using Rasch analysis, which is a probabilistic model widely used in the field of rehabilitation to evaluate the psychometric properties of scales ${ }^{24}$. This analysis allows for the difficulty of the items and the abilities of the individuals to be calibrated on the same linear continuum. This linear continuum was divided into equal intervals (logits) along which each item and individual were aligned ${ }^{24,25}$. The basic assumption of the present study was that the better the individual's balance, the greater his or her odds to score high in the investigated tests.

The analysis was performed using software Winsteps, version 3.72.3/2011 ${ }^{26}$, which calculates values such as $M n S q$ and $t$ in two formats: infit and outfit. The infit statistic is sensitive to the variation of the scores representing the subjects' abilities, and the outfit statistic reflects the occurrence of unexpected responses ${ }^{25,27}$. These values are used to establish whether the items fit with the unidimensionality concept, with values of $M n S q=1 \pm 0.4$ associated with $t= \pm 2$ being acceptable ${ }^{27}$. Erratic scores represent a threat to the validity of a test and must be revised.
The condition in which more than $5 \%$ of the items of a scale exhibit erratic scores indicate that the corresponding combination of items is not able to measure a unidimensional construct ${ }^{27}$, and a lower rate of erratic scores indicates that a particular set of items is able to define a dimension or construct ${ }^{24,25,27}$. As the BESTest comprises 36 items (taking into consideration the tasks scored separately for the right and left sides of the body), up to two (1.8 rounded) items are allowed to not fit with the model.

The Rasch model further includes the person and item separation indices, which indicate the number of ability levels among which the individuals might be distributed and the number of difficulty levels among which the items are distributed, respectively ${ }^{24,25,27}$. The number of levels among which the individuals and items could be distributed was calculated using the equation recommended by Bond and $\mathrm{Fox}^{27}$. A satisfactory test divides the subjects into at least three ability levels: low, medium, and high ${ }^{25}$. Ideally, the estimated values of reliability to calibrate the measures must be $>0.80^{27}$.

\section{Results}

\section{Sample characterization}

The average values of the parameters assessed in the group of older adults were the following: age $=73.8 \pm 7.4$ years old (65-97), body mass index $(\mathrm{BMI})=25.6 \pm 3.7(19.1-33.6)$, and MMSE $=24.5 \pm 4.3$ (13-30). Four volunteers were illiterate. In addition, most (18) of the volunteers had up to four years of schooling, eight had five to eight years, four had finished secondary school, and one had finished college. Of these 35 older adults, 26 were female, and one used a Canadian cane. In this subsample, $45.7 \%$ were married, $31.4 \%$ were widowers, $14.3 \%$ were single, and $8.5 \%$ were separated/divorced. Fourteen volunteers were sedentary, and 21 exercised using at least one of the following modalities: walking, dancing, yoga, and weight training.

The average values of the parameters assessed in the group of individuals with PD were the following: age $=66.5 \pm 10.3$ years old $(50-88), \mathrm{BMI}=$ 24.6 \pm 3.6 (17.6-32.9), MMSE $=25.5 \pm 3.3(16-31)$, UPDRS $=20.2 \pm 8.8(3-40)$, disease duration $=9.9 \pm 6.4$ years (1-27), and HY stage 2.02 \pm 0.8 (1-4). Most participants $(68.6 \%$ ) were in HY stage 1-2, with $8.6 \%$ in stage $2.5,20 \%$ in stage 3 , and $2.9 \%$ in stage 4 . Three volunteers were illiterate. In addition, most (12) of the volunteers had up to four years of schooling, seven had five to eight years, nine had finished 
secondary school, and four had finished college. Of these 35 participants, 14 were women, two used common canes, and one used a Canadian cane. In this subsample, $62.9 \%$ were married, $17.1 \%$ were widowers, $14.3 \%$ were separated/divorced, and $5.8 \%$ were single. Sixteen volunteers were sedentary, and nineteen exercised using at least one of the following modalities: walking, water aerobics, weight training, and T'ai Chi Ch'uan.

\section{Test-retest reliability}

The ICC values of both tests were adequate $(>.90)^{23}$. The ICC value of the BESTest in the population of older adults was 0.98 and was 0.92 in the individuals with PD. The ICC values of the MiniBESTest were 0.99 and 0.95 , respectively.

\section{Rasch analysis}

In the BESTest, the calibration stability of the items and individuals was 0.97 and 0.95 , respectively. The results of the Rasch analysis relative to the BESTest are described in Table 1, in which the values of the calibration or difficulty of items, $\mathrm{MnSq}$ and $t$ (infit and outfit) are individually reported. The individual separation index was 4.19 , which indicates that the items distributed the subjects among six balance ability levels. The item separation index was 5.36, which corresponds to approximately seven levels of difficulty.

In Table 1, the items are listed in decreasing order of difficulty. Item 27, "Timed Get Up \& Go With Dual Task", was the most difficult, and item 9, "Sit to Stand", was the easiest one. As a whole, the items were well distributed as virtually all the sections included items with low, medium, and high difficulty, except for the section "Biomechanical constraints", which contains items that are concentrated at the upper area of the continuum and that thus are primarily more difficult. Among the 36 items included in the test, two had erratic scores, i.e., did not fit with the model expectations, which were item 1, "Base of support", and item 23, "Walk with head turns".

Figure 1 represents a map that depicts the levels of difficulty of the items on the left and the continuum of the ability of the sample balance on the right, as measured by the BESTest. No items were aligned at the level of the individuals at either endpoint. Most items exhibited medium difficulty, whereas very easy and very difficult items, which might distinguish the individuals more accurately, were missing, although a ceiling effect did not occur. Most of the older adults exhibited medium to high abilities, and most individuals with PD exhibited medium abilities.
Among the latter, those at the initial stages of the disease $(H Y=1-2.5$; UPDRS $=17.2 \pm 7.1)$ were located at the upper area of the continuum, which denotes better balance than the individuals in the moderate and severe stages $(\mathrm{HY}=3$ and 4 ; UPDRS $=30.4 \pm 5.7)$, who clustered towards the middle and lower areas, denoting worse balance.

In the Rasch analysis of the MiniBESTest, the individual separation index was 3.16, which indicates that the items distributed the subjects among approximately four levels of balance ability. The item separation index was 6.41 , which corresponds to approximately nine levels of difficulty. The calibration stability of the items and individuals was 0.98 and 0.91 , respectively. Similar to the full version, in the MiniBESTest, "Timed Get Up \& Go With Dual Task" (item 14) was the most difficult, and "Sit to Stand" (item 1) was the easiest one. All the items fit with the model expectations (average calibration of 1.7 logits; average values of the subjects, infit $[\mathrm{MnSq}=0.98 ; t=0]$ and outfit $[\mathrm{MnS} q=0.98$ and $t=0.2]$ ); average values of the items, infit: $[M n S q=1.0$ and $t=0]$ and outfit $[M n S q=0.98$ and $t=0]$ ).

Figure 2 shows a map that depicts the continuum of the difficulty of the items on the left and the sample balance ability continuum on the right, as measured by the MiniBESTest. Similar to the full version, in this case, most items had medium difficulty, whereas items allowing the assessment of the individuals with very high or very low ability were lacking. Additionally, here, the individuals with PD exhibited a tendency to poorer balance than the older adults as the latter clustered in the upper area and the former in the middle area of the graphic. The individuals at the initial stages of PD ( $\mathrm{HY}=1-2.5$; UPDRS $=17.2 \pm 7.1$ ) tended to exhibit better balance and clustered in the upper area of the continuum, whereas those at the moderate and severe stages $(\mathrm{HY}=3$ and 4 ; UPDRS $=30.40 \pm 5.7)$ tended to exhibit poorer balance and clustered in the middle and lower areas of the graphic.

\section{Discussion}

The present study describes the versions translated and adapted to Brazilian Portuguese of new tools for balance assessment, i.e., the BESTest and MiniBESTest. The BESTest is the only test in which the items are categorized according to the balance control systems theory. This fact enables therapists to identify those individuals at risk for falls and to establish which factors contribute to the balance deficit to orient interventions ${ }^{8,28}$. 
Table 1. Calibration of BESTest items.

\section{Item}

27. SG Timed "Get Up \& Go" with dual task

4. $\mathrm{BC} \quad \mathrm{Hip} /$ trunk lateral strength

11. TR Stand on one leg $-\mathrm{E}$

11. TR Stand on one leg-D

2. BC CoM alignment

3. $\mathrm{BC}$ Ankle strength and range

23. SG Walk with head turns *

5. BC Sit on floor and standup

17. RR. Compensatory stepping correction - backward

21. SG Gait-level surface

24. SG Walk with pivot turns

19D. SO Eyes closed, foam surface

10. TR Rise to toes

7. SL Functional reach forward

1. BC Base of support*

8. SL Functional reach lateral - E

15. RR In place response - backward

8. SL Functional reach lateral - D

16. RR Compensatory stepping correction-forward

26. SG Timed "Get Up \& Go"

25. SG Step over obstacles

6. SL Lateral lean-E

6. SL Lateral lean $-\mathrm{D}$

18. RR Compensatory stepping correction -lateral-D

18. RR Compensatory stepping correction -lateral - E

12. TR Alternate stair touching

19C. SO Eyes open, foam surface

14. RR In place response - forward

22. SG Change in gait speed

6. SL Sitting verticality - D

19B. SO Eyes closed, firm surface

6. SL Sitting verticality - E

13. TR Standing arm raise

20. SO Incline-eyes closed

19A. SO Eyes open, firm surface
Infit

Outfit

Calibration Error

\begin{tabular}{|c|c|c|c|c|c|}
\hline S & שs & MnSq & $\mathbf{T}$ & MnSq & $\mathbf{t}$ \\
\hline 2.63 & .17 & 1.31 & 1.7 & 1.34 & 1.1 \\
\hline 1.59 & .16 & 1.19 & 1.2 & 1.13 & .7 \\
\hline 1.15 & .16 & .88 & -.7 & .92 & -.4 \\
\hline 1.10 & .16 & .89 & -.7 & .89 & -.5 \\
\hline 1.07 & .16 & 1.43 & 2.5 & 1.37 & 1.8 \\
\hline 1.07 & .16 & .89 & -.6 & .91 & -.4 \\
\hline 1.05 & .16 & 1.46 & 2.6 & 1.43 & 2.1 \\
\hline .79 & .16 & 1.46 & 2.5 & 1.32 & 1.6 \\
\hline .77 & .16 & .96 & -.2 & .92 & -.4 \\
\hline .74 & .16 & .45 & -4.2 & .53 & -3.1 \\
\hline .71 & .16 & 1.29 & 1.7 & 1.28 & 1.5 \\
\hline .66 & .16 & .73 & -1.8 & .79 & -1.2 \\
\hline .63 & .16 & .75 & -1.6 & .70 & -1.8 \\
\hline .38 & .17 & .70 & -1.9 & .75 & -1.4 \\
\hline .33 & .17 & 1.62 & 3.1 & 1.89 & 3.8 \\
\hline .32 & .17 & .70 & -1.9 & .85 & -.8 \\
\hline .30 & .17 & 1.33 & 1.8 & 1.46 & 2.2 \\
\hline .18 & .17 & .71 & -1.8 & .91 & -.4 \\
\hline .18 & .17 & .89 & -.6 & .90 & -.5 \\
\hline .02 & .18 & .93 & -.3 & .80 & -1.0 \\
\hline-.01 & .18 & .59 & -2.6 & .63 & -2.1 \\
\hline-.08 & .18 & .82 & -1.0 & .90 & -.5 \\
\hline-.11 & .18 & .89 & -.5 & .90 & -.5 \\
\hline-.11 & .18 & 1.23 & 1.2 & .95 & -.2 \\
\hline-.21 & .19 & 1.46 & 2.2 & 1.23 & 1.1 \\
\hline-.60 & .20 & .55 & -2.6 & .76 & -1.1 \\
\hline-.77 & .21 & .74 & -1.3 & .77 & -.9 \\
\hline-.82 & .22 & 1.16 & .8 & 1.17 & .7 \\
\hline-.97 & .23 & 1.10 & .5 & .78 & -.8 \\
\hline-1.12 & .24 & 1.12 & .6 & 1.25 & .9 \\
\hline-1.18 & .24 & .61 & -1.9 & .54 & -1.8 \\
\hline-1.36 & .25 & 1.10 & .5 & 1.09 & .4 \\
\hline-1.43 & .26 & .71 & -1.2 & .71 & -.9 \\
\hline-1.57 & .27 & 1.34 & 1.3 & .82 & -.4 \\
\hline-2.53 & .36 & .93 & -.1 & .42 & -1.2 \\
\hline-2.82 & .40 & 1.27 & .8 & 1.02 & .3 \\
\hline
\end{tabular}

Erratic items: MnSq>1.4 and t>2. Sections of the test: BC: Biomechanical constraints; SL: Stability limits; TR: Transitions Anticipatory postural adjustment; RR: Reactive postural responses; SO: Sensory orientation; SG: Stability in gait. 


\section{Logits Items| Individuals}

4

3

\section{5 (MORE SKILLED)}

$+072$

$\begin{array}{llllll}\mid & 165 & 066 & 067 & 070 & 078\end{array}$

$\mathrm{X} \mid \begin{array}{lllll}065 & 065 & 065 & \mathrm{P} 58-1 & \mathrm{P} 64-1\end{array}$

I P59-1,5 P60-2

073

| 068

$+071$

| 078

P51-1 P73-2

2

$\mathrm{X} \mid 064$

I 069

|M 071

$072 \quad 079$

P74-2 P50-1, 5

$070 \quad 089 \quad$ P $67-2$ P55-1, 5

$\mathrm{xx}$ |

1 $\mathrm{xxx}+078$

$097 \quad \mathrm{P} 65-2,5$

$073 \quad 076$

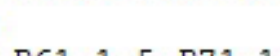

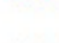

$\mathrm{XX} \mid \mathrm{P} 63-2$

$\operatorname{XxXX|} \quad 082$

$081 \quad 078$

P61-1, 5 P71-1 P71-1, 5 P76-1, 5

| $\mathrm{P} 62-2$

$\mathrm{XxXX} \mid \quad 080$

$\mathrm{XX} \quad 072$

0

$\mathrm{XXX} \mathrm{M}+073$

$\mathrm{XxX}$

088

P62-2 P55-2 P78-1, 5

P77-1 P78-3 P55-2, 5 P64-3 P77-3

P66-3

074

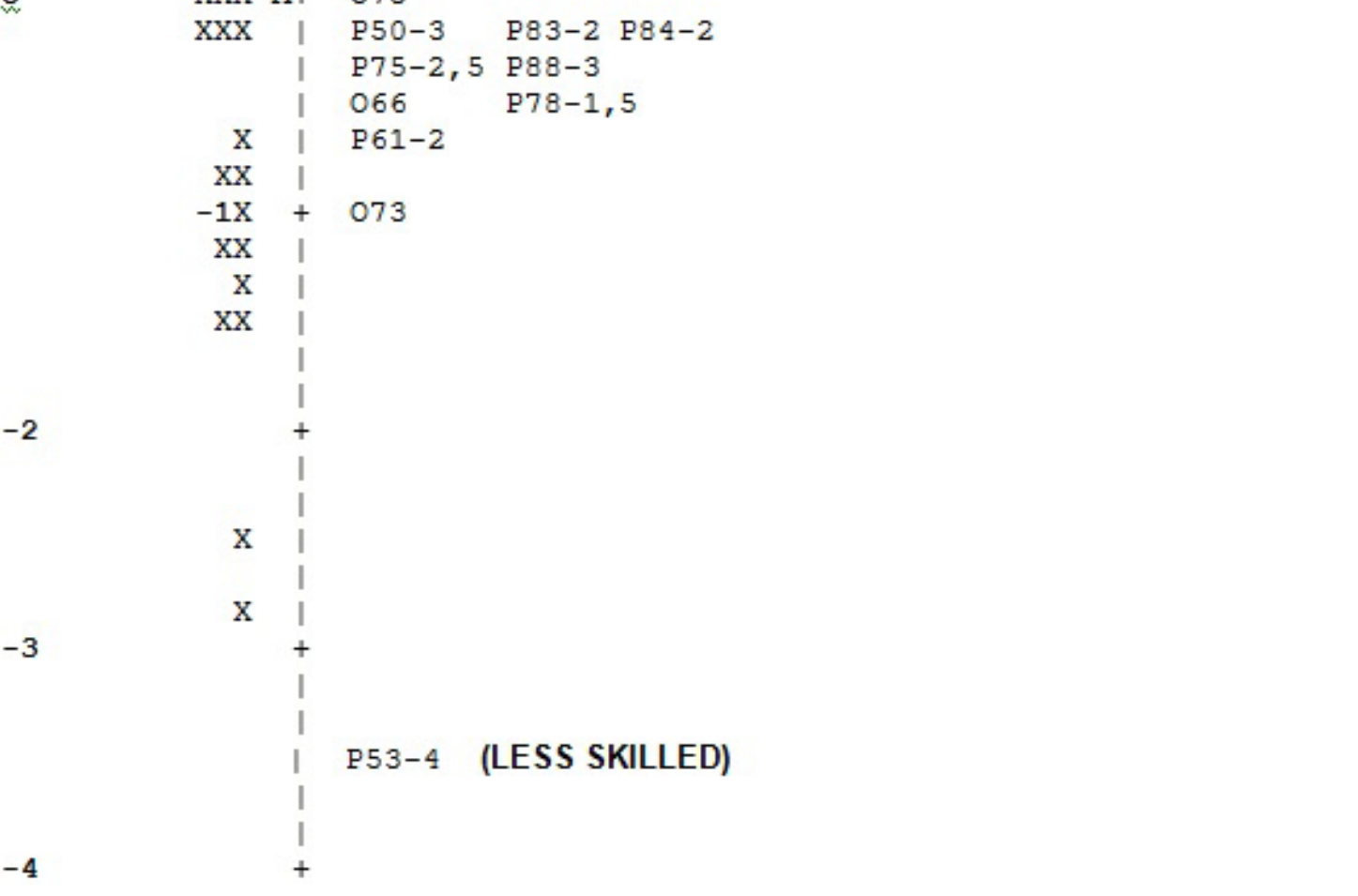

Figure 1. Map representing the distribution of people and items from equilibrium measured by the BESTest. Each " $\mathrm{X}$ " on the left represents a test item, unidentified for easy viewing. The subjects are on the right: $\mathrm{E}=$ elderly and $\mathrm{P}=$ subjects with $\mathrm{PD}$ (shaded). The next number identifies the age, and the number after the dash indicates the HY classification of the individuals with PD. M is the average of the items on the left and right sides of the subjects. 


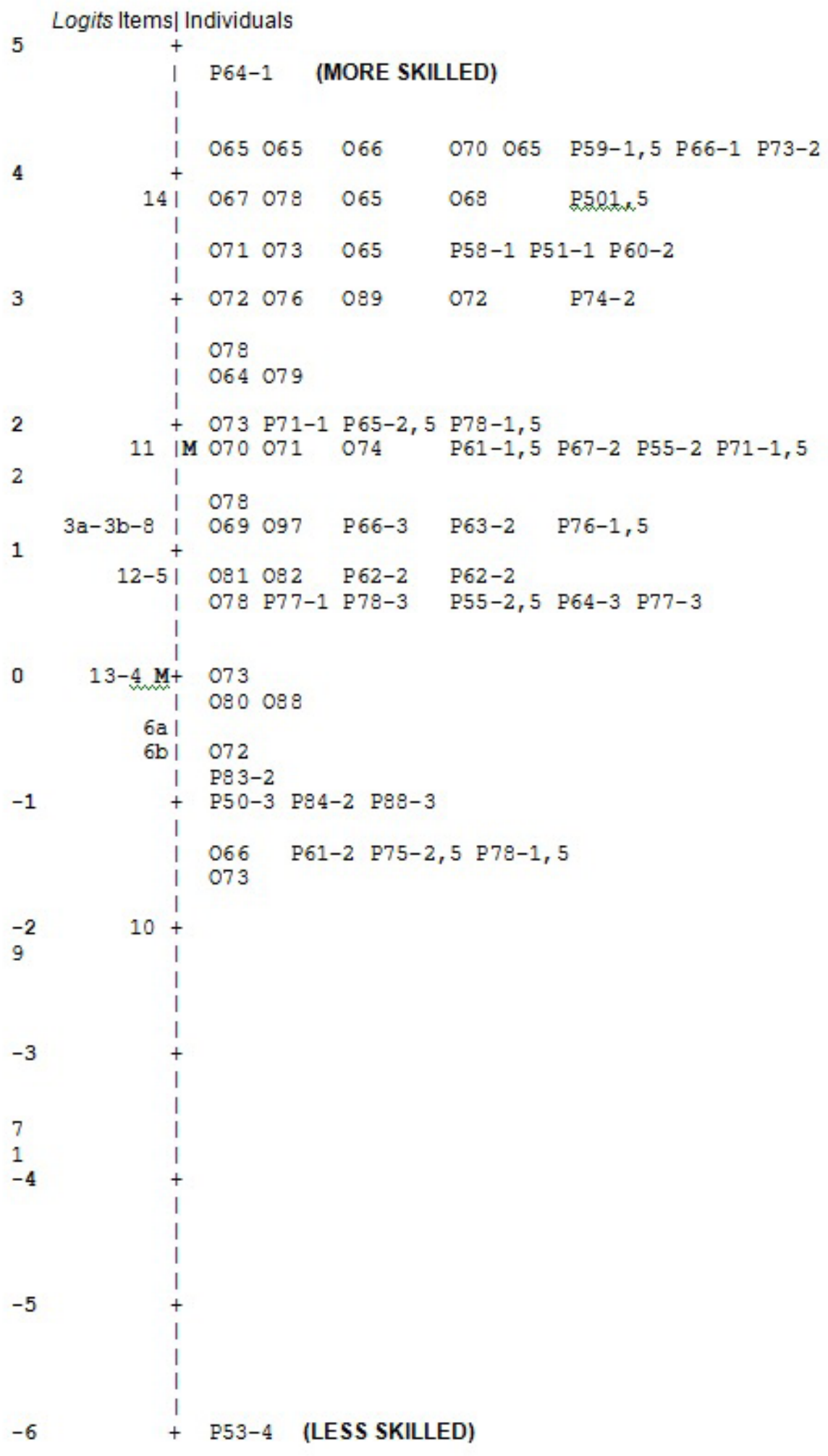

Figure 2. Map representing the distribution of subjects and items from equilibrium measured by the MiniBESTest. The numbers on the left represent the test items, and the subjects are on the right: $\mathrm{E}=$ elderly and $\mathrm{P}=$ =individuals with $\mathrm{PD}$ (shaded). The next number identifies the age, and the number after the dash identifies the HY classification of the individuals with PD. M is the average of the items on the left and right sides of the subjects. 
The Rasch analysis performed in the present study showed a calibration stability of the items and individuals in both investigated tests, indicating that the measures were stable and reproducible. In the original versions, both instruments were considered to be reliable and valid to assess balance in individuals with $\mathrm{PD}^{9,14}$

Item 27, "Timed Get Up \& Go With Dual Task", was considered to be the most difficult, which agrees with the results of another study ${ }^{29}$. The performance of cognitive tasks (e.g., doing calculations and spelling words backwards) while walking is known to make the gait unstable ${ }^{30}$, requiring a greater ability to perform the latter task. Item 9, "Sit to stand", was the least difficult and did not pose a challenge to balance in the present sample. The sample mostly comprised individuals with medium to high abilities and patients in the initial stages of PD, who were thus able to perform this task easily. Most items in the BESTest and MiniBESTest had medium difficulty (Figures 1 and 2, left side), and these tests lacked very easy and very difficult items, which would allow for the better assessment of the subjects, especially those with high performance levels. For this reason, the BESTest and MiniBESTest should be applied to populations other than the one included in the present study, such as youths and individuals with other diseases.

In the case of the BESTest, the Rasch analysis found only two erratic items ( 1 and 23); therefore, the combination of items was appropriate for the assessment of a unidimensional construct ${ }^{25,27}$. Item 1, "Base of support" is scored by the examiner (presence or not of considerable deformities) and the subject (presence or not of pain in the lower limbs) together, which might account for the erratic scores. Pain is an individual and subjective experience that might be associated or not with actual or potential tissue damage, and it can become increased by negative emotional states ${ }^{31}$. However, chronic pain might also induce adaptive behaviors, leading the affected individual to not have signs $\mathrm{s}^{32-34}$. Therefore, examiners should pay special attention to individuals with depressive and negative behavior with regards to the pain. This observation should not be used to calculate the item differentially but to collect relevant information on the functional loss. In turn, item 23, "Walk with head turns", involved two simultaneous activities: walking in a straight line and turning the head. Therefore, it is a complex task that demands quick responses from the vestibular system ${ }^{1}$, which might be affected by aging or disease ${ }^{1,3}$. Individuals with PD have difficulty in performing simultaneous activities, and as a rule, they exhibit poorer performance in one of the tasks ${ }^{35}$. Four volunteers in the present sample exhibited unexpected low scores in this item, including three older adults (O68, O69, and O78) and one individual with PD (P67; HY=2; UPDRS=25). The individuals were independent and had no dysfunctions; therefore, high scores were expected in item \#23, similarly to what was seen in other items. These four volunteers, however, exhibited the minimum score because they stopped walking to turn the head to the side, which might represent a differentiated safety strategy. In addition, as Table 1 shows, item 23 is among the most difficult tasks. Therefore, the examiners should take the issues discussed here into account upon scoring this item.

The Rasch analysis showed a tendency in both the BESTest and MiniBESTest to distinguish between the groups of older adults and individuals with PD as a function of their distribution within the continuum. The older adults exhibited medium to high balance ability levels, whereas the individuals with PD exhibited medium levels. Other studies that compared the raw scores of the BESTest between the controls and individuals with neurological diseases ${ }^{8}$ and fibromyalgia ${ }^{29}$ also found a poorer balance ability (lower scores) among the ill individuals ${ }^{8,29}$.

The decisive factor in the distribution of the individuals with PD was the severity of disease. Most of the sample $(77.1 \%)$ was at the initial stages of PD $(\mathrm{HY}=1-2.5)$ and clustered in the upper area of the continuum, whereas the participants at the moderate and severe stages, $\mathrm{HY}=3$ and $4(22.9 \%)$, clustered in the middle and lower areas of the continuum. Although the Berg Balance Scale is the instrument most widely used for the clinical assessment of balance, it exhibits a ceiling effect in milder cases of PD because those individuals attain the maximum scores $^{12,13}$. The results of the present study show that the BESTest and MiniBESTest exhibit a satisfactory ability to detect subtle balance deficits, thus making the distinction among individuals easier ${ }^{28,36}$. This ability may be due to the fact that these tests assess gait and postural responses in addition to mobility (also assessed in the Berg Balance Scale), which might be affected at the earliest stages of disease ${ }^{13}$.

With regard to the clinical application of the BESTest and MiniBESTest based on the results of Rasch analysis, the main difference between both is that the former comprises more items and that, although most exhibit medium difficulty, these items cover a wider area of the ability continuum, resulting in a greater individual separation, as expected from an instrument used for diagnostic purposes. The item calibration is more widely spaced in the Mini 
version, resulting in less precise measures. These data correspond to the expected distinction between instruments designed for diagnostic and screening purposes, respectively. In the present study, the application of the BESTest lasted 25 minutes on average, varying from 21 to 31 minutes. In the study by Jones et al..$^{29}$, the average length was 17 minutes. The application of the MiniBESTest usually requires 12 to 15 minutes $^{14,36}$. The examiners should pay attention to the instructions described in the tests, especially for the items with a tendency towards variability in the responses.

The lack of frail older adults and the small number of individuals with advanced stages of PD might represent limitations of the present study. In addition, these tests must be applied to other types of populations in further studies for their validity to be more widely assessed.

The Rasch analysis showed that the set of items that compose the Brazilian versions of the BESTest and MiniBESTest exhibits appropriate construct validity, response stability, and discriminatory capacity among various balance ability levels in older adults and individuals with PD.

\section{- Acknowledgments}

To the Conselho Nacional de Desenvolvimento Cientifico e Tecnológico - CNPq and Fundação de Amparo à Pesquisa do Estado de Minas Gerais - FAPEMIG, Brazil.

\section{References}

1. Horak FB, Macpherson JM. Postural orientation and equilibrium. In: Rowel LB, Shepherd JT, editors. Handbook of Phisiology. A critical, comprehensive presentation of physiological knowledge and concepts. New York: Oxford University Press; 1996. p. 255-92.

2. Horak FB. Postural orientation and equilibrium: what do we need to know about neural control of balance to prevent falls? Age Ageing. 2006;35 Suppl 2:ii7-ii11. PMid:16926210. http://dx.doi.org/10.1093/ageing/afl077

3. Matsumura BA, Ambrose AF. Balance in the Elderly. Clin Geriatr Med. 2006;22:395-412. PMid:16627085. http:// dx.doi.org/10.1016/j.cger.2005.12.007

4. Gonçalves DFF, Ricci NA, Coimbra AMW. Functional balance among community-dwelling older adults: a comparison of their history of falls. Rev Bras Fisioter. 2009;13(4): 316-23. http://dx.doi.org/10.1590/ S1413-35552009005000044

5. Borges LL, Garcia PA, Ribeiro SOV. Características clínico-demográficas, quedas e equilíbrio funcional de idosos institucionalizados e comunitários. Fisioter Mov. 2009;22(1):53-60.
6. Tanner C, Hubble J, Chan P, editors. Epidemiology and genetics of Parkinson>s disease. In: Watts RL, Koller WC, editors. Neurologic principles and Practice. New York: McGraw-Hill; 1996. p.137-152.

7. Lau LML, Breteler MMB. Epidemiology of Parkinson>s disease. Lancet Neurol. 2006;5:525-535. http://dx.doi. org/10.1016/S1474-4422(06)70471-9

8. Horak FB, Wrisley DM, Frank J. The Balance Evaluation Systems Test (BESTest) to Differentiate Balance Deficits. Phys Ther. 2009;89(5):484-498. PMid:19329772 PMCid:2676433. http://dx.doi.org/10.2522/ptj.20080071

9. Podsiadlo D, Richardson S. The timed "Up \& Go": a test of basic functional mobility for frail elderly persons. J Am Geriatr Soc. 1991;39:142-148. PMid:1991946.

10. Berg KO, Maki B, Williams JI, Holliday PJ, WoodDauphinée S. Clinical and laboratory measures of postural balance in an elderly population. Arch Phys Med Rehabil. 1992;70:1073-1080.

11. Tinetti ME, Inouye SK, Gill TM, Doucette JT. Shared risk factors for falls, incontinence and functional dependence: unifying the approach to geriatric syndromes. J Am Med Assoc. 1995;273:1348-1353. http://dx.doi.org/10.1001/ jama.1995.03520410042024

12. Karuka AH, Silva JAM, Navega MT. Analysis of agreement of assessment tools of body balance in the elderly. Rev Bras Fisioter. 2011;15(6):460-6. PMid:22218711. http:// dx.doi.org/10.1590/S1413-35552011000600006

13. King LA, Priest KC, Salarian A, Pierce D, Horak FB. Comparing the MiniBESTest with the Berg Balance Scale to Evaluate Balance Disorders in Parkinson's Disease. Park Dis. 2012;2012. Epub 2011 October 24. http://dx.doi. org/10.1155/2012/375419

14. Franchignoni F, Horak FB, Godi M, Nardone A, Giordano A. Using psychometric techniques to improve the balance evaluation systems test: The Mini-BESTest. J Rehabil Med. 2010;42:316-324.

15. Guillemin F, Bombardier C, Beaton DE. Crosscultural adaptation of health-related quality of life measures: literature review and proposed guidelines. J Clin Epidemiol. 1993;46:1417-1432. http://dx.doi. org/10.1016/0895-4356(93)90142-N

16. Bertolucci PH, Brucki SM, Campacci SR, Juliano Y. O mini exame do estado mental em uma população geral: impacto da escolaridade. Arq Neuropsiquiatr. 1994;52:17. PMid:8002795. http://dx.doi.org/10.1590/ S0004-282X1994000100001

17. Brucki S, Nitrini R, Caramelli P, Bertolucci PHF, Okamoto IH. Sugestões para o uso do Miniexame do estado mental no Brasil. Arq Neuropsiquiatr. 2003;61(3B):777-781. PMid:14595482. http://dx.doi.org/10.1590/ S0004-282X2003000500014

18. Beaton DE, Bombardier C, Guillemin F, Ferraz MB. Guidelines for the Process of Cross-Cultural Adaptation of Self-Report Measures. Spine (Phila Pa 1976). 2000;25(24):3186-3191. PMid:11124735. http:// dx.doi.org/10.1097/00007632-200012150-00014

19. Hoehn M, Yahr M. Parkinsonism: onset, progression and mortality. Neurology. 1967;17:427-442. http://dx.doi. org/10.1212/WNL.17.5.427 
20. Goetz CG, Poewe W, Rascol O, Sampaio C, Stebbins GT, Counsell C, et al. Movement Disorder Society Task Force Report on the Hoehn and Yahr Staging Scale: Status and Recommendations. Mov Disord. 2004;19(9):1020-1028. PMid:15372591. http://dx.doi.org/10.1002/mds.20213

21. Goulart F, Pereira LX. Uso de escalas para avaliação da doença de Parkinson em fisioterapia. Fisioter Pesqui. 2005;11(1):49-56.

22. Goetz C, Poewe W, Rascol O, Sampaio C, Stebbins GT. The Unified Parkinson's Disease Rating Scale (UPDRS): Status and Recommendations. Mov Disord. 2003;18(7):738-750. PMid:12815652. http:// dx.doi.org/10.1002/mds.10473

23. Portney LG, Watkins MP. Foundations of Clinical Research: Applications to Practice. 3rd ed. Upper Saddle River: Prentice-Hall; 2009. 892 p.

24. Kielhofner G. Research in Occuptional Therapy. Methods for Inquiry Practice. FA Davies; 2006. p.184-200.

25. Silverstein BF, Fisher WP, Kilgore KM, Harley JP, Harvey RF. Applying psychometric criteria to functional assessment in medical rehabilitation: Defining interval measures. Arch Phys Med Rehabil. 1992;73:507-518. PMid:1622298.

26. Linacre JM. Winsteps Rasch Measurement Version 3.72.3 [Software]. Available from: http://www.winsteps. com. 2011.

27. Bond TG, Fox CM. Applying the Rasch model: fundamental measurement in the human sciences. Mahwal: Lawrence Erlbaum Associates; 2001. 288 p.

28. Leddy AL, Crowner BE, Earhart GM. Functional Gait Assessment and Balance Evaluation System Test: reliability, validity, sensitivity, and specificity for identifying individuals with Parkinson disease who fall. Phys Ther. 2011;91:102-113. PMid:21071506 PMCid:3017321. http://dx.doi.org/10.2522/ptj.20100113

29. Jones KD, Horak FB, Winters KS, Morea JM, Bennett RM. Fibromyalgia is Associated with Impaired Balance and Falls. J Clin Rheumatol. 2009;15(1):16-21.
PMid:19125137 PMCid:2836495. http://dx.doi. org/10.1097/RHU.0b013e318190f991

30. Hollman JH, Kovash FM, Kubik JJ, Linbo RA. Age-related differences in spatiotemporal markers of gait stability during dual task walking.Gait Postur. 2007;26(1):113119. PMid:16959488. http://dx.doi.org/10.1016/j. gaitpost.2006.08.005

31. Da Silva JA, Ribeiro-Filho NP. Avaliação e Mensuração de Dor - Pesquisa, Teoria e Prática. São Paulo: FUNPEC; 2006. 467 p.

32. Philips HC, Grant L. The evolution of chronic back pain problems: a longitudinal study. Behav Res Ther. 1991;29(5):435-441. http://dx.doi. org/10.1016/0005-7967(91)90127-O

33. Hall AJ, Kalra L. Measuring quality of life: who should measure quality of life. BMJ. 2001;322(7299):1417-20. http://dx.doi.org/10.1136/bmj.322.7299.1417

34. Retinck ICM, Ketelaar M, Jongmans KJ, Gorter JW. Parents of children with cerebral palsy: a review of factors related to the process of adaptation. Child. 2006;33(2):161-169.

35. Berardelli A, Rothwell JC, Thompson PD, Hallett M Pathophysiology of bradykinesia in Parkinson's disease. Brain. 2001; 124: 2131-46. PMid:11673316. http://dx.doi. org/10.1093/brain/124.11.2131

36. Leddy AL, Crowner BE, Earhart GM. Utility of MiniBESTest, BESTest and BEStest sections for balance assessment in individuals with Parkinson's Disease. JNPT. 2011;35(2): 90-97. PMid:21934364 PMCid:3178037.

\section{Correspondence}

Fátima Rodrigues-de-Paula

Universidade Federal de Minas Gerais

Departamento de Fisioterapia

Av. Antônio Carlos, 6627, Campus Pampulha CEP 31270-010, Belo Horizonte, MG, Brazil

e-mail: fatimarp@ufmg.br; fatimarp@globo.com 


\section{BESTest \\ Avaliação do Equilíbrio - Teste dos Sistemas \\ NÚMERO DOTESTE/CÓDIGO DO INDIVÍDUO NOME DO EXAMINADOR}

DATA

1

Instruções do BESTest para o EXAMINADOR

1. Os indivíduos devem ser testados com sapatos sem salto ou sem sapatos e meias.

2. Se o indivíduo precisar de um dispositivo de auxílio para um item, pontue aquele item em uma categoria mais baixa.

Equipamentos necessários

- Cronômetro

- Fita métrica fixada na parede para o Teste de Alcance Funcional (Functional Reach Test)

- Um bloco da espuma Tempur ${ }^{\circledR}$ (densidade média) de $10 \mathrm{~cm}$ de altura e com aproximadamente $60 \times 60 \mathrm{~cm}$

- Rampa de $10^{\circ}$ de inclinação (pelo menos $60 \times 60 \mathrm{~cm}$ ) para ficar de pé

- Degrau de escada, $15 \mathrm{~cm}$ de altura para tocar os pés alternadamente

- Duas caixas de sapato empilhadas para servir de obstáculo durante a marcha

- Peso livre de 2,5 kg para levantamento rápido do braço

- Cadeira firme com braços e marcação no chão com fita 3 metros à frente para o Teste "Timed Get Up and Go"

- Fita crepe para marcar 3 metros e 6 metros no chão para o Teste "Timed Get Up and Go"

\section{RESUMO DO DESEMPENHO: CALCULAR PORCENTAGEM DE PONTUAÇÃO}

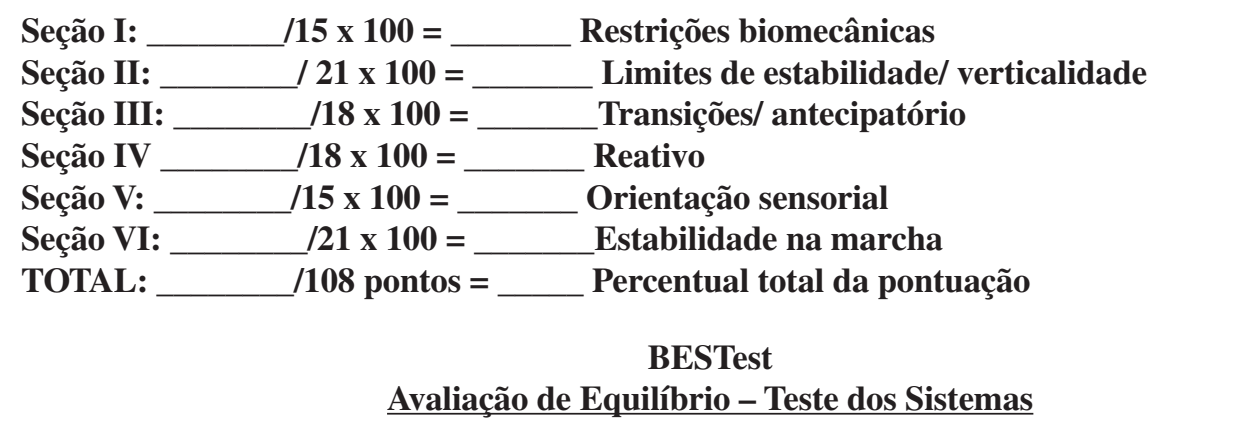

Os indivíduos devem ser testados com sapatos sem salto ou sem sapatos e meias. Se o indivíduo precisar de dispositivo de auxílio para um item, pontue aquele item em uma categoria mais baixa. Se o indivíduo requerer assistência física para executar um item, pontue na categoria mais baixa (0) para aquele item.

\section{RESTRIÇÔES BIOMECÂNICAS}

(SEÇÃO I:

1. BASE DE APOIO

/15 PONTOS)

(3) Normal: Ambos os pés têm base de apoio normal sem deformidades ou dor.

(2) Um pé tem deformidade e/ou dor.

(1) Ambos os pés têm deformidades ou dor.

(0) Ambos os pés têm deformidades e dor.

2. ALINHAMENTO DO CENTRO DE MASSA (CDM) (*AP: ÂNTERO-POSTERIOR; *ML: MÉDIO-LATERAL)

(3) Alinhamento normal AP e ML do CDM e alinhamento postural segmentar normal.

(2) Alinhamento anormal AP ou ML do CDM ou alinhamento postural segmentar anormal.

(1) Alinhamento anormal AP ou ML do CDM e alinhamento postural segmentar anormal.

(0) Alinhamento anormal AP $\underline{\text { e ML do CDM. }}$ 


\section{FORÇA E AMPLITUDE DE TORNOZELO}

(3) Normal: Capaz de ficar na ponta dos pés com altura máxima e ficar nos calcanhares com a ponta dos pés para cima

(2) Comprometimento dos flexores ou extensores do tornozelo em um dos pés (i. e. menos que a altura máxima)

(1) Comprometimento nos dois grupos do tornozelo (i. e. flexores bilaterais ou ambos flexores e extensores de tornozelo de um pé)

(0) Ambos flexores e extensores nos tornozelos direito e esquerdo comprometidos (i.e. menos que altura máxima)

4. FORÇA LATERAL DE QUADRIL/ TRONCO

(3) Normal: Abduz ambos os quadris para levantar o pé do chão durante $10 \mathrm{~s}$ enquanto mantém o tronco na vertical

(2) Leve: Abduz ambos os quadris para levantar o pé do chão durante $10 \mathrm{~s}$, mas não mantém tronco na vertical

(1) Moderada: Abduz apenas um quadril para levantar o pé do chão durante $10 \mathrm{~s}$ com tronco na vertical

(0) Grave: Não abduz nenhum dos quadris para levantar o pé do chão durante $10 \mathrm{~s}$ com o tronco na vertical ou não

5. SENTAR NO CHÃO E LEVANTAR (Tempo segundos).

(3) Normal: Senta e levanta do chão independentemente

(2) Leve: Usa uma cadeira para sentar no chão ou para levantar

(1) Moderado: Usa uma cadeira para sentar no chão e para levantar

(0) Grave: Não senta no chão nem levanta, mesmo com uma cadeira, ou se recusa

II. LIMITES DE ESTABILIDADE (SEÇÃO II:

/21 PONTOS)

\section{VERTICALIDADE SENTADO E INCLINAÇÃO LATERAL}

\section{Inclinação}

E D

(3) (3) Inclinação máxima, o indivíduo move os ombros além da linha média do corpo, muito estável

(2) (2) Inclinação moderada, o ombro do indivíduo se aproxima da linha média do corpo ou há alguma instabilidade

(1) (1) Inclinação muito pequena, ou instabilidade significativa

(0) (0) Sem inclinação ou cai (excede os limites)

\section{Verticalidade}

E D

(3) (3) Realinha para vertical com muito pouco ou nenhum movimento em excesso

(2) (2) Movimentos significativos a mais ou a menos, mas eventualmente realinha para a vertical

(1) (1) Falha ao realinhar para a vertical

(0) (0) Cai com os olhos fechados

7. ALCANCE FUNCIONAL PARA FRENTE (Distância alcançada: $\mathrm{cm})$

(3) Máximo para os limites: $>32 \mathrm{~cm}$

(2) Moderado: $16,5 \mathrm{~cm}-32 \mathrm{~cm}$

(1) Pobre: $<16,5 \mathrm{~cm}$

(0) Inclinação não mensurável - ou deve ser pego

8. ALCANCE FUNCIONAL LATERAL (Distância alcançada: Esquerdo cm; Direito cm)

Esquerdo Direito
(3)
(3) Máximo para o limite: $>25,5 \mathrm{~cm}$
(2)
(2) Moderado: $10-25,5 \mathrm{~cm}$
(1)
(1) Pobre: $<10 \mathrm{~cm}$
(0)
(0) Inclinação não mensurável, ou deve ser pego 
III. TRANSIÇÕES-AJUSTES POSTURAIS ANTECIPATÓRIOS .. (SEÇÃO III: 9. SENTADO PARA DE PÉ

/18 PONTOS)

(3) Normal: Passa para de pé sem a ajuda das mãos e se estabiliza independentemente

(2) Passa para de pé na primeira tentativa com o uso das mãos

(1) Passa para de pé após várias tentativas ou requer assistência mínima para ficar de pé ou se estabilizar ou requer tocar a parte de trás das pernas na cadeira

(0) Requer assistência moderada ou máxima para ficar de pé

10. FICAR NA PONTA DOS PÉS

(3) Normal: Estável por $3 \mathrm{~s}$ com boa altura

(2) Calcanhares levantados, mas não na amplitude máxima (menor que quando segurando com as mãos, então não requer equilíbrio) ou instabilidade leve e mantém por $3 \mathrm{~s}$

(1) Mantém por menos que $3 \mathrm{~s}$

(0) Incapaz

11. DE PÉ EM UMA PERNA

Esquerdo - Tempo em segundos:

(3) Normal: Estável por $>20 \mathrm{~s}$

Direito - Tempo em segundos:

(2) Movimentação do tronco OU 10-20 s

(3) Normal: Estável por $>20 \mathrm{~s}$

(1) De pé 2-10 s

(2) Movimentação do tronco OU 10-20 s

(0) Incapaz

(1) De pé 2-10 s

(0) Incapaz

\section{TOCAR DEGRAU ALTERNADAMENTE}

Número de toques bem sucedidos: ; Tempo em segundos:

(3) Normal: Fica de pé independentemente e com segurança e completa oito toques em $<10 \mathrm{~s}$

(2) Completa oito toques (10-20 s) E/OU mostra instabilidade como posicionamento inconsistente do pé, movimento excessivo de tronco, hesitação ou sem ritmo

(1) Completa <oito toques sem assistência mínima (i.e. dispositivos auxiliares) OU > 20 s para oito toques

(0) Completa <oito toques, mesmo com dispositivo auxiliar

\section{DE PÉ, LEVANTAR O BRAÇO}

(3) Normal: Permanece estável

(2) Oscilação visível

(1) Passos para recuperar equilíbrio/incapaz de mover-se rapidamente sem perder o equilíbrio

(0) Incapaz, ou necessita assistência para estabilidade

IV. RESPOSTAS POSTURAIS REATIVAS (SEÇÃO IV: /18 PONTOS)

\section{RESPOSTA NO LUGAR - PARA FRENTE}

(3) Recupera a estabilidade com os tornozelos, sem movimentação adicional de braços ou quadris

(2) Recupera estabilidade com algum movimento de braços ou quadris

(1) Dá um passo para recuperar a estabilidade

(0) Cairia se não fosse pego OU requer ajuda OU não tenta

15. RESPOSTA NO LUGAR - PARA TRÁS

(3) Recupera a estabilidade com os tornozelos, sem movimentação adicional de braços ou quadris

(2) Recupera estabilidade com algum movimento de braços ou quadris

(1) Dá um passo para recuperar a estabilidade

(0) Cairia se não fosse pego OU requer assistência OU não tenta 


\section{CORREÇÃO COM PASSO COMPENSATÓRIO - PARA FRENTE}

(3) Recupera independentemente com passo único e amplo (segundo passo para realinhamento é permitido)

(2) Mais de um passo usado para recuperar o equilíbrio, mas recupera a estabilidade independentemente OU um passo com desequilíbrio

(1) Dá vários passos para recuperar o equilíbrio, ou necessita de assistência mínima para prevenir uma queda

(0) Nenhum passo OU cairia se não fosse pego OU cai espontaneamente

17. CORREÇÃO COM PASSO COMPENSATÓRIO - PARA TRÁS

(3) Recupera independentemente com passo único e amplo

(2) Mais de um passo usado, mas estável e recupera independentemente OU um passo com desequilíbrio

(1) Dá vários passos para recuperar o equilíbrio, ou necessita de assistência mínima

(0) Nenhum passo OU cairia se não fosse pego OU cai espontaneamente

18. CORREÇÃO COM PASSO COMPENSATÓRIO - LATERAL

Esquerdo

(3) Recupera independentemente com um passo de comprimento/largura normais (cruzado ou lateral permitido)

(2) Muitos passos usados, mas recupera independentemente

(1) Dá passos, mas necessita de ser auxiliado para prevenir uma queda

(0) Cai, ou não consegue dar passo $\underline{\text { Direito }}$

(3) Recupera independentemente com um passo de comprimento/largura normais (cruzado ou lateral permitido)

(2) Muitos passos usados, mas recupera independentemente

(1) Dá passos, mas necessita de ser auxiliado para prevenir uma queda

(0) Cai, ou não consegue dar passo

V. ORIENTAÇÃO SENSORIAL

(SEÇÃO V:

/15 PONTOS)

19. INTEGRAÇÃO SENSORIAL PARA O EQUILÍBRIO (CTSIB MODIFICADO)

\begin{tabular}{|c|c|c|c|}
\hline $\begin{array}{l}\text { A - OLHOS ABERTOS, } \\
\text { SUPERFÍCIE FIRME }\end{array}$ & $\begin{array}{c}\text { B - OLHOS_FECHADOS, } \\
\text { SUPERFÍCIE FIRME }\end{array}$ & $\begin{array}{l}\text { C - OLHOS ABERTOS, } \\
\text { SUPERFÍCIE DE ESPUMA }\end{array}$ & $\begin{array}{l}\text { D - OLHOS FECHADOS, } \\
\text { SUPERFÍCIE DE ESPUMA }\end{array}$ \\
\hline Tentativa $1 \_s$ & Tentativa $1 \_$s & Tentativa $1 \_\mathrm{s}$ & Tentativa $1 \_s$ \\
\hline Tentativa $2 \ldots s$ & Tentativa $2 \ldots \mathrm{s}$ & Tentativa $2 \ldots \mathrm{s}$ & Tentativa $2 \ldots \mathrm{s}$ \\
\hline (3) 30 s estável & (3) 30 s estável & (3) 30 s estável & (3) 30 s estável \\
\hline (2) 30 s instável & (2) 30 s instável & (2) 30 s instável & (2) 30 s instável \\
\hline (1) $<30 \mathrm{~s}$ & (1) $<30 \mathrm{~s}$ & (1) $<30 \mathrm{~s}$ & $(1)<30 \mathrm{~s}$ \\
\hline (0) Incapaz & (0) Incapaz & (0) Incapaz & (0) Incapaz \\
\hline
\end{tabular}

\section{INCLINAÇÃO - OLHOS FECHADOS}

Dedos apontados para o topo

(3) Fica de pé independentemente, estável sem oscilação excessiva, mantém por $30 \mathrm{~s}$, e alinha com a gravidade

(2) Fica de pé independentemente 30 s com maior oscilação que no item 19-B OU alinha com a superfície

(1) Requer auxílio pelo toque OU fica de pé sem assistência por 10-20 s

(0) Incapaz de ficar de pé >10 s OU não tenta ficar de pé independentemente 
VI. ESTABILIDADE NA MARCHA

(SEÇÃO V:

/21 PONTOS)

21. MARCHA - SUPERFÍCIE PLANA (Tempo

s)

(3) Normal: Anda $6 \mathrm{~m}$, com boa velocidade ( $\leq 5,5 \mathrm{~s})$, sem evidência de desequilíbrio

(2) Leve: $6 \mathrm{~m}$, com velocidade menor (>5,5 s), sem evidência de desequilíbrio

(1) Moderado: anda $6 \mathrm{~m}$, com evidência de desequilíbrio (base larga, movimento lateral do tronco, trajetória de passos inconsistente) - em qualquer velocidade preferida

(0) Grave: não consegue andar $6 \mathrm{~m}$ sem assistência OU desvios graves de marcha OU desequilíbrio grave

22. MUDANÇA NA VELOCIDADE DA MARCHA

(3) Normal: Muda a velocidade da marcha significativamente sem desequilíbrio

(2) Leve: Incapaz de mudar velocidade da marcha sem desequilíbrio

(1) Moderado: Muda a velocidade da marcha, mas com sinais de desequilíbrio

(0) Grave: Incapaz de alcançar mudança significativa da velocidade E sinais de desequilíbrio

23. ANDAR COM VIRADAS DE CABEÇA - HORIZONTAL

(3) Normal: realiza viradas de cabeça sem mudar a velocidade da marcha e bom equilíbrio

(2) Leve: realiza viradas de cabeça suavemente com redução da velocidade da marcha

(1) Moderado: realiza viradas de cabeça com desequilíbrio

(0) Grave: realiza viradas de cabeça com velocidade reduzida E desequilíbrio E/OU não movimenta a cabeça na amplitude disponível enquanto anda

\section{ANDAR E GIRAR SOBRE O EIXO}

(3) Normal: Gira com pés próximos RÁPIDO ( $\leq 3$ passos) com bom equilíbrio

(2) Leve: Gira com pés próximos DEVAGAR ( $\geq 4$ passos) com bom equilíbrio

(1) Moderado: Gira com pés próximos em qualquer velocidade com sinais leves de desequilíbrio

(0) Grave: Não consegue girar com pés próximos em qualquer velocidade e desequilíbrio significativo

25. PASSAR SOBRE OBSTÁCULOS (Tempo segundos)

(3) Normal: capaz de passar sobre as duas caixas de sapato empilhadas sem mudar a velocidade e com bom equilíbrio

(2) Leve: passa sobre duas caixas de sapato empilhadas mas reduz a velocidade, com bom equilíbrio

(1) Moderado: passa sobre as duas caixas de sapato empilhadas com desequilíbrio ou as toca

(0) Grave: não consegue passar sobre as caixas E reduz a velocidade com desequilíbrio ou não consegue realizar com assistência

26. “GET UP \& GO” CRONOMETRADO (Tempo segundos)

(3) Normal: Rápido (<11 s) com bom equilíbrio

(2) Leve: Devagar (>11 s) com bom equilíbrio

(1) Moderado: Rápido (<11 s) com desequilíbrio

(0) Grave: Devagar (>11 s) E desequilíbrio

27. "GET UP \& GO" CRONOMETRADO COM DUPLA TAREFA (Tempo segundos)

(3) Normal: Nenhuma mudança notável entre sentado e de pé, no ritmo ou precisão da contagem regressiva e nenhuma mudança na velocidade da marcha

(2) Leve: Desaceleração notável, hesitação ou erros na contagem regressiva OU marcha lenta (em 10\%) na dupla tarefa

(1) Moderado: Afeta AMBAS: afeta a tarefa cognitiva E diminui a velocidade de marcha $(\mathrm{em}>10 \%)$ na dupla tarefa

(0) Grave: Não consegue contar regressivamente enquanto anda ou para de andar enquanto fala 


\section{INSTRUÇÕES PARA O BESTEST}

\section{RESTRIÇÕES BIOMECÂNICAS}

\section{BASE DE APOIO}

Instruções para o examinador: Examine detalhadamente ambos os pés procurando por deformidades ou queixas de dor, assim como supinação/pronação anormais, ausência ou anormalidade nos dedos dos pés, dor de fasceíte plantar, bursite, etc.

\section{ALINHAMENTO DO CDM}

Instruções pra o examinador: Olhe o paciente de lado e imagine uma linha vertical passando através do seu centro de massa corporal (CDM) até os pés. (O CDM é um ponto imaginário dentro ou fora do corpo em torno do qual o corpo rodaria se flutuasse no espaço). Em um adulto, ereto de pé, uma linha vertical através do CDM até a superfície de apoio está alinhada à frente das vértebras na altura do umbigo e passa aproximadamente $2 \mathrm{~cm}$ à frente do maléolo lateral, centrada entre os dois pés. Alinhamentos posturais segmentares anormais, tais como escoliose ou cifose ou assimetrias, podem ou não afetar o alinhamento do CDM.

\section{FORÇA \& AMPLITUDE DE TORNOZELO}

Instruções para o examinador: Peça ao paciente para repousar a ponta dos dedos das mãos em suas mãos para apoio enquanto ele fica de pé sobre a ponta dos pés, o mais alto possível e depois, fica de pé sobre os calcanhares.

Observe a altura do calcanhar e o levantamento dos dedos do pé.

\section{FORÇA LATERAL DE QUADRIL/ TRONCO}

Instruções para o examinador: Peça ao paciente para repousar a ponta dos dedos das mãos em suas mãos enquanto levanta a perna para o lado tirando-a do chão e mantém. Conte 10 segundos enquanto o pé está fora do chão com o joelho esticado. Se ele usar força moderada em suas mãos para manter o tronco verticalmente, pontue como se ele não tivesse mantido o tronco na vertical.

\section{SENTAR NO CHÃO E LEVANTAR}

Instruções para o examinador: Comece com o paciente de pé perto de uma cadeira firme. Considere que o paciente está sentado quando ambos os glúteos estiverem bem apoiados no chão. Se a tarefa levar mais de 2 minutos para ser completada, com ou sem a cadeira, pontue $=0$. Se o paciente necessitar de alguma assistência física, pontue $=0$.

\section{LIMITES DE ESTABILIDADE}

\section{VERTICALIDADE E INCLINAÇÃO LATERAL}

Instruções pra o examinador: O paciente deve estar sentado confortavelmente em uma superfície firme, nivelada, sem braços (banco ou cadeira), com os pés bem apoiados no chão. É permito levantar o ísquio ou pés quando inclinar. Observe se o paciente retorna à posição vertical suavemente sem movimentar a mais nem a menos. Pontue a pior execução de cada lado.
Paciente: Fique de pé com pés descalços e me diga se atualmente tem alguma dor nos pés ou tornozelos ou pernas.

Paciente: Fique de pé, relaxado, olhando diretamente para frente.

Paciente: Repouse os dedos nas minhas mãos para apoio enquanto fica de pé sobre a ponta dos pés.Agora fique sobre os calcanhares, levantando os dedos dos pés. Mantenha cada posição por 3 segundos.

Paciente: Repouse levemente seus dedos nas minhas mãos enquanto levanta sua perna para o lado no ar e mantenha a posição até eu falar para parar. Tente manter seu tronco vertical enquanto você sustenta sua perna no ar.

Paciente: Você é capaz de sentar no chão e depois levantar em menos de 2 minutos? Se você precisar usar a cadeira para ajudar a ir ao chão ou para levantar-se, vá em frente, mas sua pontuação será afetada. Avise-me caso você não possa sentar no chão e se levantar sem a minha ajuda.

Paciente: Cruze seus braços no peito. Posicione seus pés na largura dos ombros. Eu pedirei a você que feche os olhos e incline para um lado o máximo que conseguir. Você deve manter sua coluna reta e inclinar para o lado o máximo que você conseguir sem perder o equilíbrio OU usar suas mãos. Mantendo seus olhos fechados, retorne à posição inicial depois que tiver inclinado o máximo que conseguir. É permitido levantar os glúteos ou pés. Feche os olhos e incline agora. (Repita para o outro lado) 


\section{ALCANCE FUNCIONAL PARA FRENTE}

Instruções para o examinador: O examinador deve colocar uma régua no final da ponta dos dedos do indivíduo, quando seus braços estiverem a $90^{\circ}$ de flexão. O paciente não pode levantar os calcanhares, rodar o tronco ou protrair a escápula excessivamente. $\mathrm{O}$ paciente deve manter os braços paralelos à régua e pode usar o braço menos envolvido. A medida registrada é a máxima distância horizontal alcançada pelo paciente. Registre o melhor alcance.

\section{ALCANCE FUNCIONAL LATERAL}

Instruções para o examinador: Peça para o indivíduo alinhar bem os pés, para que as pontas dos dedos das mãos, com os braços abduzidos a $90^{\circ}$, estejam no começo da régua. A medida registrada é a distância máxima horizontal alcançada pelo paciente. Registre o melhor alcance. Certifique-se de que o indivíduo começou no neutro. É permitido ao paciente levantar um calcanhar do chão, mas não o pé inteiro.
Paciente: Fique de pé normalmente. Por favor, levante ambos os braços esticados a sua frente, com as pontas dos dedos mantidas alinhadas. Estique seus dedos e alcance para frente o máximo que conseguir. Não levante os calcanhares. Não toque a régua ou a parede. Uma vez tendo alcançado o mais longe que conseguir, por favor, retorne à posição de pé normal. Eu pedirei a você que faça isso duas vezes. Alcance o mais longe que conseguir.

Paciente: Fique de pé normalmente com os pés na largura dos ombros. Braços ao lado. Levante o braço para o lado. Seus dedos não devem tocar a régua. Alongue seus dedos e alcance o mais longe que conseguir. Não levante os dedos do pé do chão. Alcance o mais longe que conseguir. (REPITA para o outro lado)

\section{TRANSIÇÕES - AJUSTES POSTURAIS ANTECIPATÓRIOS}

\section{SENTADO PARA DE PÉ}

Instruções para o examinador: Note o início do movimento e o apoio das mãos nos braços da cadeira ou nas coxas ou o movimento de jogar os braços para frente.

\section{FICAR NA PONTA DOS PÉS}

Instruções para o examinador: Permita ao paciente tentar duas vezes. Registre a melhor pontuação. (Se suspeitar que o indivíduo esteja usando menos que sua altura máxima, peça a ele que levante enquanto segura nas mãos do examinador.) Certifique-se de que o indivíduo olha para um alvo a 1,2 - 3,6 $\mathrm{m}$ de distância.

\section{DE PÉ EM UMA PERNA}

Instruções para o examinador: Permita ao paciente duas tentativas e registre a melhor. Registre em segundos o quanto ele mantém a posição, até um máximo de 30 segundos. Pare de contar quando o indivíduo tirar suas mãos dos quadris ou colocar o pé no chão.

\section{TOCAR DEGRAU ALTERNADAMENTE}

Instruções para o examinador: Use um degrau padrão com altura de 15 centímetros. Conte o número de toques bem sucedidos e o tempo total para completar oito toques. É permitido que o indivíduo olhe para seus pés.

\section{DE PÉ, LEVANTAR O BRAÇO}

Instruções para o examinador: Use um peso de $2,5 \mathrm{~kg}$. Faça o indivíduo ficar de pé e levantar o peso com ambas as mãos até altura dos ombros. O indivíduo deve realizar isso o mais rápido que puder. Diminua a pontuação em uma categoria se o peso utilizado precisar ser menor que $2,5 \mathrm{~kg}$ ou se levantar $<75^{\circ}$.
Paciente: Cruze os braços na frente do peito. Tente não usar as mãos a menos que você precise. Não deixe suas pernas encostarem na cadeira quando ficar de pé. Por favor, levante agora.

Paciente: Posicione seus pés na largura dos seus ombros. Coloque suas mãos nos quadris. Tente se elevar o mais alto possível sobre a ponta dos pés. Eu contarei em voz alta até 3 segundos. Tente manter essa posição por, no mínimo, 3 segundos. Olhe diretamente para frente. Levante agora.

Paciente: Olhe diretamente para frente. Mantenha suas mãos no quadril. Dobre uma perna para trás. Não toque a perna levantada na outra perna. Fique de pé sobre uma perna o máximo de tempo que conseguir. Olhe diretamente para frente. Levante agora. (REPITA DO OUTRO LADO)

Paciente: Coloque suas mãos nos quadris. Toque a ponta de cada pé alternadamente no degrau. Continue até que cada pé toque o degrau quatro vezes (total de oito toques). Eu cronometrarei o quão rápido você consegue fazer isso. Comece agora.

Paciente: Levante esse peso com ambas as mãos de uma posição a sua frente até a altura dos ombros. Por favor, faça isso o mais rápido que puder. Mantenha seus cotovelos esticados enquanto você levantar e mantenha. Mantenha até que eu conte até 3 . Comece agora. 


\section{RESPOSTAS POSTURAIS REATIVAS}

\section{RESPOSTA NO LUGAR - PARA FRENTE}

Instruções para o examinador: Fique de frente para o paciente, coloque uma mão em cada ombro e empurre levemente o paciente para trás até que os músculos anteriores do tornozelo contraiam (e os dedos dos pés comecem a estender), então solte subitamente. Não permita nenhuma inclinação antecipada pelo paciente. Pontue a melhor de duas tentativas se o paciente estiver despreparado ou caso você tenha empurrado muito forte.

\section{RESPOSTA NO LUGAR - PARA TRÁS}

Instruções para o examinador: Fique de pé atrás do paciente, coloque uma mão em cada escápula e empurre isometricamente o paciente, até seus calcanhares estarem quase levantados, não permita movimento do tronco. Solte subitamente. Não permita nenhuma inclinação antecipada do paciente. Pontue a melhor de duas respostas se o paciente estiver despreparado ou se empurrar forte demais.
Paciente: Para os próximos testes, eu irei empurrá-lo para testar suas reações de equilíbrio. Fique de pé em sua postura normal com os pés na largura dos ombros, braços ao lado do corpo. Não permita que minhas mãos o empurrem para trás. Quando eu soltar, mantenha seu equilíbrio sem dar um passo.

Paciente: Fique de pé com seus pés na distância dos ombros, braços ao lado do corpo. Não permita que minhas mãos o empurrem para frente. Quando eu soltar, mantenha o equilíbrio sem dar um passo.

\section{CORREÇÃO COM PASSO COMPENSATÓRIO - PARA FRENTE}

Instruções para o examinador: Fique de pé em frente e ao lado do paciente com uma mão em cada ombro e peça a ele que empurre para frente. (Certifique-se de que há espaço para que ele dê um passo à frente). Peça a ele que se incline até que seus ombros e quadris estejam à frente dos seus pés. Solte subitamente seu apoio quando o indivíduo estiver posicionado. Esse teste deve elicitar um passo. Esteja preparado para segurar o paciente.

\section{CORREÇÃO COM PASSO COMPENSATÓRIO - PARA TRÁS}

Instruções para o examinador: Fique de pé atrás e do lado do paciente com uma mão em cada escápula e peça para ele inclinar para trás. (Certifique-se de que há espaço para que ele dê um passo para trás). Peça a ele que incline até que seus ombros e quadris estejam atrás dos seus calcanhares. Solte o seu apoio quando o indivíduo estiver no lugar. O teste deve elicitar um passo.
Paciente: Fique de pé com seus pés na largura dos ombros, braços ao lado do corpo. Incline para frente contra minhas mãos além dos seus limites anteriores. Quando eu soltar, faça o que for necessário, incluindo dar um passo para prevenir uma queda.

\section{CORREÇÃO COM PASSO COMPENSATÓRIO - LATERAL}

Instruções para o examinador: Fique atrás do paciente, coloque uma mão no lado direito (ou esquerdo) da pelve, e peça a ele que incline seu corpo todo verticalmente na sua mão. Peça que ele incline até que a linha média da pelve esteja além do pé direito (ou esquerdo) e depois solte subitamente o apoio.

\section{ORIENTAÇÃO SENSORIAL}

\section{INTEGRAÇÃO SENSORIAL PARA EQUILÍBRIO (CTSIB MODIFICADO)}

Instruções para o examinador: Faça os testes em ordem. Registre o tempo que o paciente foi capaz de ficar em pé em cada condição até o máximo de 30 segundos. Repita a condição se ele não for capaz de ficar de pé por $30 \mathrm{~s}$ e registre ambas as tentativas (média por categoria). Utilize a espuma de média densidade Tempur ${ }^{\circledR}$, de 10 centímetros de espessura. Auxilie o indivíduo a pisar sobre a espuma. Faça o indivíduo pisar fora da espuma entre as tentativas. Inclua inclinação ou estratégia do quadril durante uma tentativa como "instabilidade".
Paciente: Fique de pé com seus pés na largura dos ombros, braços ao lado do corpo. Incline para trás contra minhas mãos além dos seus limites posteriores. Quando eu soltar, faça o que for necessário, incluindo dar um passo para prevenir uma queda.

NOTA: Esteja preparado para segurar o paciente.

Paciente: Fique de pé com seus pés juntos, braços para baixo ao lado do corpo. Incline em direção à minha mão além do seu limite lateral. Quando eu soltar, dê um passo se precisar, para evitar uma queda.

NOTA: Esteja preparado para segurar o paciente.

Paciente: Para as próximas quatro avaliações, você estará de pé nesta espuma ou no chão normal, com seus olhos abertos ou fechados. Posicione suas mãos nos seus quadris. Posicione seus pés juntos até quase se tocarem. Olhe diretamente para frente. A cada tempo, permaneça o mais estável possível até que eu diga pare. 


\section{INCLINAÇÃO - OLHOS FECHADOS}

Instruções para o examinador: Ajude o paciente a subir na rampa. Assim que o paciente fechar os olhos, comece a cronometrar. Repita a condição se não for capaz de ficar de pé por 30 segundos e faça a média de ambas as tentativas. Note se a oscilação é maior do que quando de pé em superfície plana com olhos fechados (Item 19B) ou se há pobre alinhamento com a vertical. Assistência inclui uso de bengala ou toque leve a qualquer momento durante a tentativa.

\section{ESTABILIDADE NA MARCHA}

\section{MARCHA - SUPERFÍCIE PLANA}

Instruções para o examinador: Coloque duas marcas separadas por uma distância de 6 metros visíveis para o paciente em uma superfície plana. Use um cronômetro para cronometrar a duração da marcha. Faça o indivíduo começar com os dedos dos pés na marca. Comece a cronometrar quando o primeiro pé deixa o chão e pare de cronometrar quando ambos os pés pararem além da marca seguinte.

\section{MUDANÇA NA VELOCIDADE}

Instruções para o examinador: Permita ao paciente dar 2-3 passos na sua velocidade normal, e então diga "rápido", após 2-3 passos rápidos, diga "devagar". Permita 2-3 passos lentos antes que ele pare de andar.

\section{ANDAR COM VIRADAS DE CABEÇA - HORIZONTAL}

Instruções para o examinador: Peça para o paciente virar a cabeça e manter como se olhasse por cima do ombro até que você diga a ele para olhar sobre o ombro oposto, a cada 2-3 passos. Se o paciente tiver restrições cervicais, permita movimentos combinados de cabeça e tronco (em bloco).

\section{ANDAR E GIRAR SOBRE O EIXO}

Instruções para o examinador: Demonstre um giro sobre o eixo. Uma vez que o paciente esteja andando em velocidade normal, diga "gire e pare." Conte os passos desde o giro até que o indivíduo esteja estável. Instabilidade é indicada por ampla largura de passo, passo extra ou movimentação de tronco e braço.

\section{PASSAR SOBRE OBSTÁCULOS}

Instruções para o examinador: Posicione as duas caixas empilhadas $(22,9 \mathrm{~cm})$ a 3 metros de distância de onde o paciente começará a andar. Use um cronômetro para cronometrar a duração da marcha para calcular a velocidade média ao dividir o número de segundos por 6 metros. Procure por hesitação, passos curtos e toque no obstáculo.

\section{6. "GET UP \& GO” CRONOMETRADO}

Instruções para o examinador: Faça o paciente sentar com as costas contra a cadeira. Cronometre o paciente desde a hora em que disser "vá" até que ele retorne para sentar na cadeira. Pare de cronometrar quando os glúteos do paciente tocarem o assento da cadeira. A cadeira deve ser firme, com braços, para ele se empurrar, se necessário.

FERRAMENTAS: FITA NO CHÃO 3 METROS À FRENTE DAS PERNAS DA CADEIRA.
Paciente: Por favor, fique de pé na rampa inclinada com os dedos dos pés apontados na direção do topo da rampa. Posicione seus pés na largura dos ombros. Coloque suas mãos nos seus quadris. Vou começar a cronometrar quando você fechar seus olhos.

Paciente: Caminhe na sua velocidade normal desde aqui, passe a próxima marca e pare.

Paciente: Comece andando na sua velocidade normal, quando eu lhe disser "rápido", ande o mais rápido que conseguir. Quando eu disser "devagar", ande bem vagarosamente.

Paciente: Comece andando na velocidade normal, quando eu disser "direita", vire sua cabeça e olhe para a direita. Quando eu disser "esquerda", vire sua cabeça e olhe para a esquerda. Tente manter-se andando em uma linha reta.

Paciente: Comece andando na sua velocidade normal. Quando eu disser "gire e pare", gire o mais rápido que puder para olhar na direção oposta e pare. Após o giro, seus pés devem estar próximos.

Paciente: Comece andando na sua velocidade normal. Quando você chegar às caixas de sapato, passe por cima delas, não em volta delas, e continue andando.

Paciente: Quando eu disser "vá", levante-se da cadeira, ande na sua velocidade normal através da fita no chão, gire, e volte para sentar na cadeira. Eu vou cronometrar quanto tempo isso levará. 


\section{7. “GET UP \& GO” CRONOMETRADO COM DUPLA TAREFA}

Instruções para o examinador: Antes de começar, pratique com o paciente como contar regressivamente de 3 em 3 a partir de um número entre 90 e 100 para ter certeza de que ele pode realizar a tarefa cognitiva. Então peça que ele conte regressivamente a partir de um número diferente e, depois de alguns números, diga "vá" para a tarefa 'GET UP AND $G O$ '. Cronometre o paciente a partir de quando você disser "vá" até quando ele retornar para sentar. Pare de cronometrar quando os glúteos do paciente tocarem o assento da cadeira. A cadeira deve ser firme com braços para ele se empurrar, se necessário.
Paciente: a) Conte de trás para frente de 3 em 3 começando de $100 \mathrm{OU}$ b) Liste alguns números aleatoriamente e, quando eu disser "vá," levante-se da cadeira, ande na sua velocidade normal através da fita no chão, gire e volte para sentar na cadeira, mas continue listando os números.

Anexo 2. Versão traduzida para o português-Brasil do MiniBESTest.

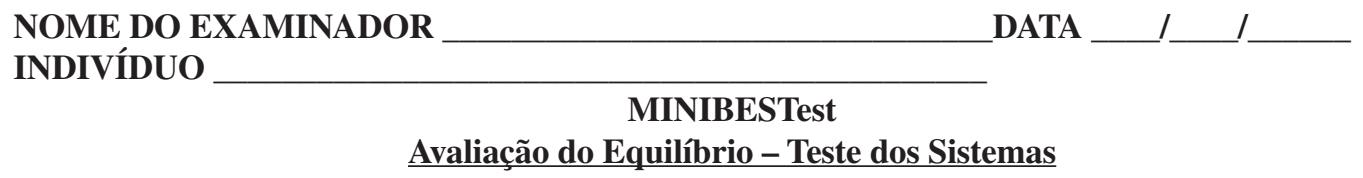

Os indivíduos devem ser testados com sapatos sem salto ou sem sapatos nem meias.

Se o indivíduo precisar de um dispositivo de auxílio para um item, pontue aquele item em uma categoria mais baixa.

Se o indivíduo precisar de assistência física para completar um item, pontue na categoria mais baixa (0) para aquele item.

1. SENTADO PARA DE PÉ

(2) Normal: Passa para de pé sem a ajuda das mãos e se estabiliza independentemente

(1) Moderado: Passa para de pé na primeira tentativa $\underline{\mathrm{COM}}$ o uso das mãos

(0) Grave: Impossível levantar de uma cadeira sem assistência - $\underline{\mathrm{OU}}$ - várias tentativas com uso das mãos

\section{FICAR NA PONTA DOS PÉS}

(2) Normal: Estável por $3 \mathrm{~s}$ com altura máxima

(1) Moderado: Calcanhares levantados, mas não na amplitude máxima (menor que quando segurando com as mãos) OU instabilidade notável por $3 \mathrm{~s}$

(0) Grave: $\leq 3 \mathrm{~s}$

\section{DE PÉ EM UMA PERNA}

Esquerdo

Tempo (em segundos)Tentativa 1:

\section{Tentativa 2:}

(2) Normal: $20 \mathrm{~s}$

(1) Moderado: <20 s

(0) Grave: Incapaz $\underline{\text { Direito }}$

Tempo (em segundos) Tentativa 1:

Tentativa 2:

(2) Normal: $20 \mathrm{~s}$

(1) Moderado: $<20 \mathrm{~s}$

(0) Grave: Incapaz

\section{CORREÇÃO COM PASSO COMPENSATÓRIO - PARA FRENTE}

(2) Normal: Recupera independentemente com passo único e amplo (segundo passo para realinhamento é permitido)

(1) Moderado: Mais de um passo usado para recuperar o equilíbrio

(0) Nenhum passo, OU cairia se não fosse pego, OU cai espontaneamente

\section{CORREÇÃO COM PASSO COMPENSATÓRIO - PARA TRÁS}

(2) Normal: Recupera independentemente com passo único e amplo

(1) Moderado: Mais de um passo usado para recuperar o equilíbrio

(0) Grave: Nenhum passo, OU cairia se não fosse pego, OU cai espontaneamente 


\section{CORREÇÃO COM PASSO COMPENSATÓRIO - LATERAL}

Esquerdo

(2) Normal: Recupera independentemente com um passo (cruzado ou lateral permitido)

(1) Moderado: Muitos passos para recuperar o equilíbrio

(0) Grave: Cai, ou não consegue dar passo
Direito

(2) Normal: Recupera independentemente com um passo (cruzado ou lateral permitido)

(1) Moderado: Muitos passos para recuperar o equilíbrio

(0) Grave: Cai, ou não consegue dar passo

7. OLHOS ABERTOS, SUPERFÍCIE FIRME (PÉS JUNTOS) (Tempo em segundos:

(2) Normal: $30 \mathrm{~s}$

(1) Moderado: $<30 \mathrm{~s}$

(0) Grave: Incapaz

8. OLHOS FECHADOS, SUPERFÍCIE DE ESPUMA (PÉS JUNTOS) (Tempo em segundos:

(2) Normal: $30 \mathrm{~s}$

(1) Moderado: $<30 \mathrm{~s}$

(0) Grave: Incapaz

9. INCLINAÇÃO - OLHOS FECHADOS (Tempo em segundos:

(2) Normal: Fica de pé independentemente $30 \mathrm{~s}$ e alinha com a gravidade

(1) Moderado: Fica de pé independentemente $<30$ s OU alinha com a superfície

(0) Grave: Incapaz de ficar de pé >10 s OU não tenta ficar de pé independentemente

10. MUDANÇA NA VELOCIDADE DA MARCHA

(2) Normal: Muda a velocidade da marcha significativamente sem desequilíbrio

(1) Moderado: Incapaz de mudar velocidade da marcha ou desequilíbrio

(0) Grave: Incapaz de atingir mudança significativa da velocidade E sinais de desequilíbrio

\section{ANDAR COM VIRADAS DE CABEÇA - HORIZONTAL}

(2) Normal: realiza viradas de cabeça sem mudança na velocidade da marcha e bom equilíbrio

(1) Moderado: realiza viradas de cabeça com redução da velocidade da marcha

(0) Grave: realiza viradas de cabeça com desequilíbrio

12. ANDAR E GIRAR SOBRE O EIXO

(2) Normal: Gira com pés próximos, RÁPIDO ( $\leq 3$ passos) com bom equilíbrio

(1) Moderado: Gira com pés próximos, DEVAGAR ( $\geq 4$ passos) com bom equilíbrio

(0) Grave: Não consegue girar com pés próximos em qualquer velocidade sem desequilíbrio

\section{PASSAR SOBRE OBSTÁCULOS}

(2) Normal: capaz de passar sobre as caixas com mudança mínima na velocidade e com bom equilíbrio

(1) Moderado: passa sobre as caixas, porém as toca ou demonstra cautela com redução da velocidade da marcha

(0) Grave: não consegue passar sobre as caixas OU hesita OU contorna

14. “GET UP \& GO” CRONOMETRADO (ITUG) COM DUPLA TAREFA (TUG: $s ; T U G$ dupla tarefa s)

(2) Normal: Nenhuma mudança notável entre sentado e de pé na contagem regressiva e nenhuma mudança na velocidade da marcha no TUG

(1) Moderado: A tarefa dupla afeta a contagem OU a marcha

(0) Grave: Para de contar enquanto anda OU para de andar enquanto conta 


\section{INSTRUÇÕES PARA O MINIBESTEST}

\section{SENTADO PARA DE PÉ}

Instruções para o examinador: Note o início do movimento e o apoio das mãos nos braços da cadeira ou nas coxas, ou o movimento de jogar os braços para frente.

\section{FICAR NA PONTA DOS PÉS}

Instruções para o examinador: Permita que o paciente tente duas vezes. Registre a melhor pontuação. (Se suspeitar de que o indivíduo esteja usando menos que sua altura máxima, peça a ele que levante enquanto segura nas suas mãos). Certifique-se de que o indivíduo olha para um alvo fixo a 1,2 - 3,6 metros de distância.

\section{DE PÉ EM UMA PERNA}

Instruções para o examinador: Permita que o paciente tente duas vezes e registre a melhor tentativa. Registre em segundos o quanto ele mantém a posição, até um máximo de 30 segundos. Pare de contar quando o indivíduo tirar suas mãos dos quadris ou colocar o pé no chão. Certifique-se de que o indivíduo olha para um alvo fixo a 1,2 - 3,6 metros de distância.

\section{CORREÇÃO COM PASSO COMPENSATÓRIO - PARA FRENTE}

Instruções para o examinador: Fique de pé em frente e ao lado do paciente com uma mão em cada ombro e peça a ele que empurre para frente. (Certifique-se de que há espaço para que ele dê um passo à frente). Peça a ele que se incline até que seus ombros e quadris estejam à frente dos seus pés. Solte subitamente seu apoio quando o indivíduo estiver posicionado. Mantenha pressão constante até antes dos calcanhares se levantarem. O teste deve elicitar um passo. Esteja preparado para segurar o paciente.

\section{CORREÇÃO COM PASSO COMPENSATÓRIO - PARA TRÁS}

Instruções para o examinador: Fique de pé atrás e do lado do paciente com uma mão em cada escápula e peça que ele se incline para trás. (Certifique-se de que há espaço para que ele dê um passo para trás). Peça a ele que se incline até que seus ombros e quadris estejam atrás dos seus calcanhares. Solte subitamente seu apoio quando o indivíduo estiver posicionado. Mantenha pressão constante até antes dos calcanhares se levantarem. O teste deve elicitar um passo. Esteja preparado para segurar o paciente

\section{CORREÇÃO COM PASSO COMPENSATÓRIO - LATERAL}

Instruções para o examinador: Fique atrás do paciente, coloque uma mão no lado direito (ou esquerdo) da pelve, e peça a ele que incline seu corpo todo verticalmente na sua mão. Peça que ele incline até que a linha média da pelve esteja além do pé direito (ou esquerdo) e depois solte subitamente o apoio. Esteja preparado para segurar o paciente se necessário.

\section{OLHOS ABERTOS, SUPERFÍCIE FIRME}

Instruções para o examinador: Registre o tempo que o paciente for capaz de se manter de pé até um máximo de 30 segundos.Inclua inclinação ou estratégia do quadril como "instabilidade", pontuando uma categoria inferior.
Paciente: Cruze os braços na frente do peito. Tente não usar as mãos, a menos que você precise. Não deixe suas pernas encostarem na cadeira quando ficar de pé. Por favor, levante agora.

Paciente: Posicione seus pés na largura dos seus ombros. Coloque suas mãos nos quadris. Tente se elevar o mais alto possível sobre a ponta dos pés. Eu contarei em voz alta até 3 segundos. Tente manter essa posição por, no mínimo, 3 segundos. Olhe diretamente para frente. Levante agora.

Paciente: Olhe diretamente para frente. Mantenha suas mãos nos quadris. Dobre uma perna para trás. Não toque a perna levantada na outra perna. Fique de pé sobre uma perna o máximo de tempo que conseguir. Olhe diretamente para frente. Levante agora. (REPITA DO OUTRO LADO)

Paciente: Fique de pé com seus pés na largura dos ombros, braços ao lado do corpo. Incline para frente contra minhas mãos além dos seus limites anteriores. Quando eu soltar, faça o que for necessário, incluindo dar um passo para prevenir uma queda.

NOTA: Esteja preparado para segurar o paciente.

Paciente: Fique de pé com seus pés na largura dos ombros, braços ao lado do corpo. Incline para trás contra minhas mãos além dos seus limites posteriores. Quando eu soltar, faça o que for necessário, incluindo dar um passo para prevenir uma queda.

NOTA: Esteja preparado para segurar o paciente.

Paciente: Fique de pé com seus pés juntos, braços para baixo ao lado do corpo. Incline em direção à minha mão além do seu limite lateral. Quando eu soltar, dê um passo, se precisar, para evitar uma queda.

NOTA: Esteja preparado para segurar o paciente.

Paciente: Coloque as mãos nos quadris. Coloque seus pés juntos, até quase se tocarem. Olhe diretamente para frente. A cada tempo, permaneça o mais estável possível até que eu diga pare. 


\section{OLHOS FECHADOS, SUPERFÍCIE DE ESPUMA}

Instruções para o examinador: Use uma espuma Tempur ${ }^{\circledR}$ de média densidade, com $10 \mathrm{~cm}$ de espessura. Ajude o indivíduo a subir na espuma. Diga ao paciente "Feche os olhos". Registre o tempo que o paciente foi capaz de manter a posição até um máximo de 30 segundos. Faça o paciente pisar fora da espuma entre as tentativas. Inclua inclinação ou estratégia do quadril como "instabilidade", pontuando uma categoria inferior.

(Shumway-Cook A and Horak RB. Assessing the influence of sensory interaction on balance. Physical Therapy. 66: $1548,1550,1986$.

\section{INCLINAÇÃO, OLHOS FECHADOS}

Instruções para o examinador: Ajude o paciente a subir na rampa. Assim que o paciente fechar os olhos, comece a cronometrar, registre e faça a média de duas tentativas. Note se a oscilação é maior que quando de pé com os olhos fechados em uma superfície firme e plana, ou se há um pobre alinhamento com a vertical. Assistência inclui uso de bengala ou toque leve a qualquer momento da testagem.

\section{MUDANÇA NA VELOCIDADE}

Instruções para o examinador: Permita que o paciente dê 2-3 passos na sua velocidade normal, e então diga "rápido", após 2-3 passos rápidos, diga "devagar". Permita 2-3 passos lentos antes que ele pare de andar.

\section{ANDAR COM VIRADAS DE CABEÇA - HORIZONTAL}

Instruções para o examinador: Permita que o paciente atinja sua velocidade normal e dê o comando "direita, esquerda" a cada 3-5 passos. Pontue se observar problemas em cada direção. Se o paciente apresentar restrição cervical grave, permita movimentação combinada da cabeça e tronco (em bloco).

\section{ANDAR E GIRAR SOBRE O EIXO}

Instruções para o examinador: Demonstre um giro sobre o eixo. Uma vez que o paciente esteja andando em velocidade normal, diga "gire e pare." Conte os passos desde o giro até que o indivíduo esteja estável. Instabilidade é indicada por ampla largura de passo, passo extra ou movimentação de tronco e braço.

\section{PASSAR SOBRE OBSTÁCULOS}

Instruções para o examinador: Posicione a caixa $(22,9 \mathrm{~cm}$ de altura) a $3 \mathrm{~m}$ de distância de onde o paciente começará a andar. Use um cronômetro para cronometrar a duração da marcha, para calcular a velocidade média ao dividir o número de segundos por $6 \mathrm{~m}$. Procure por hesitação, passos curtos e toque no obstáculo.

\section{4. “GET UP \& GO” CRONOMETRADO COM DUPLA TAREFA}

Instruções para o examinador: Use o escore do TUG para determinar os efeitos da dupla tarefa.

1) TUG: Comece com o paciente sentado com as costas apoiadas na cadeira. Marque o tempo a partir de quando você disser "vá" até ele voltar e sentar na cadeira. Pare de cronometrar quando as nádegas do indivíduo tocarem o assento da cadeira. A cadeira deve ser firme com braços para ele se empurrar se necessário.

2) TUG com dupla tarefa: Enquanto sentado, determine quão rápido e precisamente o paciente pode contar regressivamente de $3 \mathrm{em} 3$, a partir de um número entre 90 e 100. Então, peça a ele que conte a partir de um número diferente e, depois de alguns números, diga "vá". Cronometre a partir do momento que disser "vá" até que ele volte para a posição sentada.
Paciente: Coloque as mãos nos quadris. Coloque seus pés juntos, até quase se tocarem. Olhe diretamente para frente. A cada tempo, permaneça o mais estável possível até que eu diga pare.

Paciente: Eu irei cronometrar a próxima testagem. Por favor, fique de pé na rampa inclinada com os dedos dos pés apontados na direção do topo da rampa. Posicione seus pés na largura dos ombros. Coloque suas mãos nos seus quadris. Vou começar a cronometrar quando você fechar seus olhos.

Paciente: Comece andando na sua velocidade normal, quando eu disser "rápido", ande o mais rápido que conseguir. Quando eu disser "devagar", ande bem vagarosamente.

Paciente: Comece andando na velocidade normal, quando eu disser "direita", vire sua cabeça e olhe para a direita. Quando eu disser "esquerda", vire sua cabeça e olhe para a esquerda. Tente manter-se andando em uma linha reta.

Paciente: Comece andando na sua velocidade normal. Quando eu disser "gire e pare", gire o mais rápido que puder para olhar na direção oposta e pare. Após o giro, seus pés devem estar próximos.

Paciente: Comece andando na sua velocidade normal. Quando você chegar na caixa, passe por cima dela, não em volta dela, e continue andando.

\section{Paciente:}

1) TUG: Quando eu disser "vá", levante da cadeira, ande na sua velocidade normal através da fita no chão, gire e volte para sentar-se na cadeira.

2) TUG com dupla tarefa: Conte regressivamente de $3 \mathrm{em}$ 3, começando em __. Quando eu disser "vá", levante da cadeira, ande na sua velocidade normal através da fita no chão, gire e volte para sentar na cadeira. Continue contando regressivamente o tempo todo. 